\title{
FOLLOWING, OTHERING, TAKING OVER
}

\author{
Research Participants Redefining the Field through \\ Mobile Communication Technology
}

Nanneke Winters

\begin{abstract}
Based on fieldwork with migrants and border populations in Central America and the story of a young Congolese woman in particular, this article discusses how research participants' use of mobile communication technology provokes a redefinition of the ethnographic field. Increasingly popular trajectory research often sets out to follow migrants, yet a focus on migrants keeping in touch with researchers at their own initiative and discretion, following them, reveals entanglements of selective on- and offline engagement and self-representation. Critical exploration of research participants' differentiated use of digital technology for navigating a social environment that includes the researcher herself not only transforms our understanding of the field in empirical, ethical, and methodological terms, but also counteracts potentially voyeuristic and life-threatening practices of following people on the move.
\end{abstract}

Keywords: Central America, migrant journeys, mobile methods, navigation, online connectivity and disconnectivity, right to opacity, trajectory research

What happens when research participants employ mobile communication technology to take over the conversation? This article is inspired by Stella, ${ }^{1}$ a participant in research on transatlantic and trans-American migrant trajectories in Central America who used her smartphone to share, curate, and contest our field encounters and transformed my understanding of the ethnographic field. I met Stella, a Congolese woman in her twenties who fled South Africa during a xenophobic attack, right after she crossed the Darién jungle between Colombia and Panama. Our on-again, off-again communication taught me to think differently about migrants' navigation of this volatile social environment and the role of mobile communication technology in navigating it. I also began to see 
new possibilities in the unsettled off- and online contours of our research field, the agency of our research participants, and possible strategies for offering nonviolent portrayals of them.

This article is based on intermittent fieldwork with migrants and border populations in Costa Rica, Panama, and Honduras in 2017, 2019, and 2020, part of the research project "African Trajectories across Central America: Displacements, Transitory Emplacements, and Migration Nodes," carried out together with Heike Drotbohm at the Johannes Gutenberg University Mainz. ${ }^{2}$ In what follows, I first sketch the ongoing concern with migrant journeys and trajectory research that surrounds this fieldwork. I then offer a glimpse of Stella's role in redefining the field. I had set out to 'follow migrants', but eventually found Stella following me through her own particular use of mobile communication technology.

\section{Migrant Journeys and Trajectory Research}

Following the "twists and turns" of migrant trajectories (Schapendonk and Steel 2014: 263) is rapidly becoming a popular way to explore the experiences of people on the move. A trajectory approach to migration has conceptual as well as methodological advantages. It allows us to recognize and analyze the journey in between migrants' (shifting) points of departure and arrival, the mobilities and immobilities entailed, and the multiple actors, encounters, strategies, sentiments, and infrastructures involved. It also allows us to keep up, to a certain extent, with the rapidly changing conditions of travel as journeys unfold.

Trajectory research usually involves visiting, interviewing, and hanging out with migrants during their journey, traveling their trail or even traveling alongside them, often complemented by at-distance fieldwork through calling and texting. The multi-sited and creative use of methods that this traveling and tracing requires has been significantly facilitated by increased access to cheap mobile communication technology. Although some scholars question an overly enthusiastic celebration of the uniqueness and adequacy of so-called mobile methods (Merriman 2014), ${ }^{3}$ there is now a burgeoning methodological literature in mobilities and migration research claiming that a world characterized by movement, instability, and interconnectivity demands that our methods also be on the move or at least attuned to mobility (Salazar et al. 2017). Such mobility-attuned methods are often infused with digital and visual techniques (e.g., Walton 2017), including accompanying travelers, recording photograph and video diaries, and participating in online communities.

It is well established that migrants themselves make extensive use of these new technologies, although the differences in access and know-how that facilitated or obstructed communication across distance before also engender a 
'digital divide’ today (Benítez 2006). From classic accounts of migrants' transnational coordination with close family members via borrowed landlines (e.g., Mahler 2001), to more recent accounts of migrants seeking assistance, contacting brokers, and finding one's way via smartphones (e.g., Zijlstra and van Liempt 2017), the increased ubiquity of mobile communication technology is undoubtedly shaping current-day journeys and our understanding of them.

Bridging scholarly attention to researchers keeping in touch with migrants, on the one hand, and migrants keeping in touch with their own networks, on the other, I focus on the critical moment in which these two ways of connecting converge, and migrants begin to keep in touch with researchers at their own initiative and discretion, following them, as it were. This focus allows me to address the 'dark side' of following migrants. While proximity is often considered essential for ethnographic validity, following migrants may also open the door to voyeuristic (De León 2015) and life-threatening (Khosravi 2018) research practice. This article highlights how people on the move use the same technologies that are often employed for subjugating them (Andersson 2014) to perceive, structure, shape, make sense of, and entangle others in their trajectories through (interrupted) online connectivity. Highlighting this crucial side to migrant journeys counteracts migrant Othering. Furthermore, protecting the safety of both researcher and research participants required visiting, revisiting, and reconnecting with migrants at certain points along their way, instead of literally accompanying them as they traveled.

\section{Redefining the Field}

The presence and visibility of African and Caribbean travelers in Central America has recently increased. Their north-bound journeys are often illegalized, rerouted, and halted for indefinite periods of time (Drotbohm and Winters 2021). For migrants like Stella, part of their journey consists of crossing the Darién jungle between Colombia and Panama, following the paths of predecessors such as Colombian refugees (Girot 2002) in extremely dangerous and exhausting conditions. Walking and sometimes traveling parts of the trek in small boats, they depend on the goodwill of their co-travelers, border police, and indigenous guides for getting through. Those who make it spend some time in a state-run depot turned reception facility in La Peñita, a Panamanian village of less than 200 people that has often hosted hundreds of migrants at a time (Winters 2019). There are other indigenous communities that host migrants along the way, but in La Peñita they need to await registration by the border police, as well as biometric checks, vaccination, and permission to become part of a binational 'controlled flow' that takes them into Costa Rica (ibid.; see also Yates 2019). 
Although I never managed to gain formal access to La Peñita's shelter, not even when teaming up with local humanitarian organizations, it was clear from my attempted visits that the site was isolated, securitized, and lacking in many ways. I learned more about the conditions in and around the shelter after I got to know Stella. We met at the end of February 2019 in a health clinic in Metetí, a small town located about an hour's drive from La Peñita, where I was interviewing the secretary about the reception and treatment of migrants in this chronically understaffed clinic. While we were talking, the secretary received a phone call regarding a pregnant migrant and her companion who were brought in by helicopter because the former was malita (in bad shape). I witnessed the arrival of the couple and a migration officer, their confusion over the right documents, which delayed Stella's treatment, and the companion being sent away to the shelter in La Peñita. After her treatment, Stella asked for help, but she did not speak Spanish, so the young male border agent stationed at the clinic asked me to find out what she needed. As he was not allowed into the maternity ward, we shared a few moments outside of state control in which Stella could use my phone to let her family in South Africa and Europe know where she was. I recommended that she try to stay as long as possible at the clinic, as I thought the shelter was not appropriate for anyone, let alone a woman who was seven months pregnant and had just undergone emergency treatment for an infection. However, when I returned the next day to see how she was doing, she had already been taken to La Peñita.

But Stella kept in touch. Gradually the timidity and fear that I perceived when we first met seemed to give way to determination. Via our smartphones, she started sending me photographs of people waiting in line for food, for a bath in the village river, or for their phones to charge and receive Internet connectivity (see fig. 1), and of dirty mattresses in an overcrowded space, accompanied with messages about the lack of care and information. She also shared her desperation to get out of La Peñita:

There is no network here but when I get next to the Wi-Fi I will try my best for this message to be sent. In case my family asks you just tell them the same. If they have a way to come and fetch me please tell them to do so [because] this way it's too much for me I might lose my life even ... I just feel so alone, this place, it's practically hell, people are fighting, it's so dirty, we are sleeping and living in terrible conditions. If they can fetch me to even take me back to Congo it's fine but I can't stay here.

The sense of isolation and the lack of proper sanitation, drinking water, safety, privacy, and freedom of movement made Stella feel desperate. Some migrants might consider applying for asylum because of these conditions, but there is limited access to accurate information and procedures. In addition, getting refugee status in Panama is notoriously difficult. I kept Stella in the loop of the 


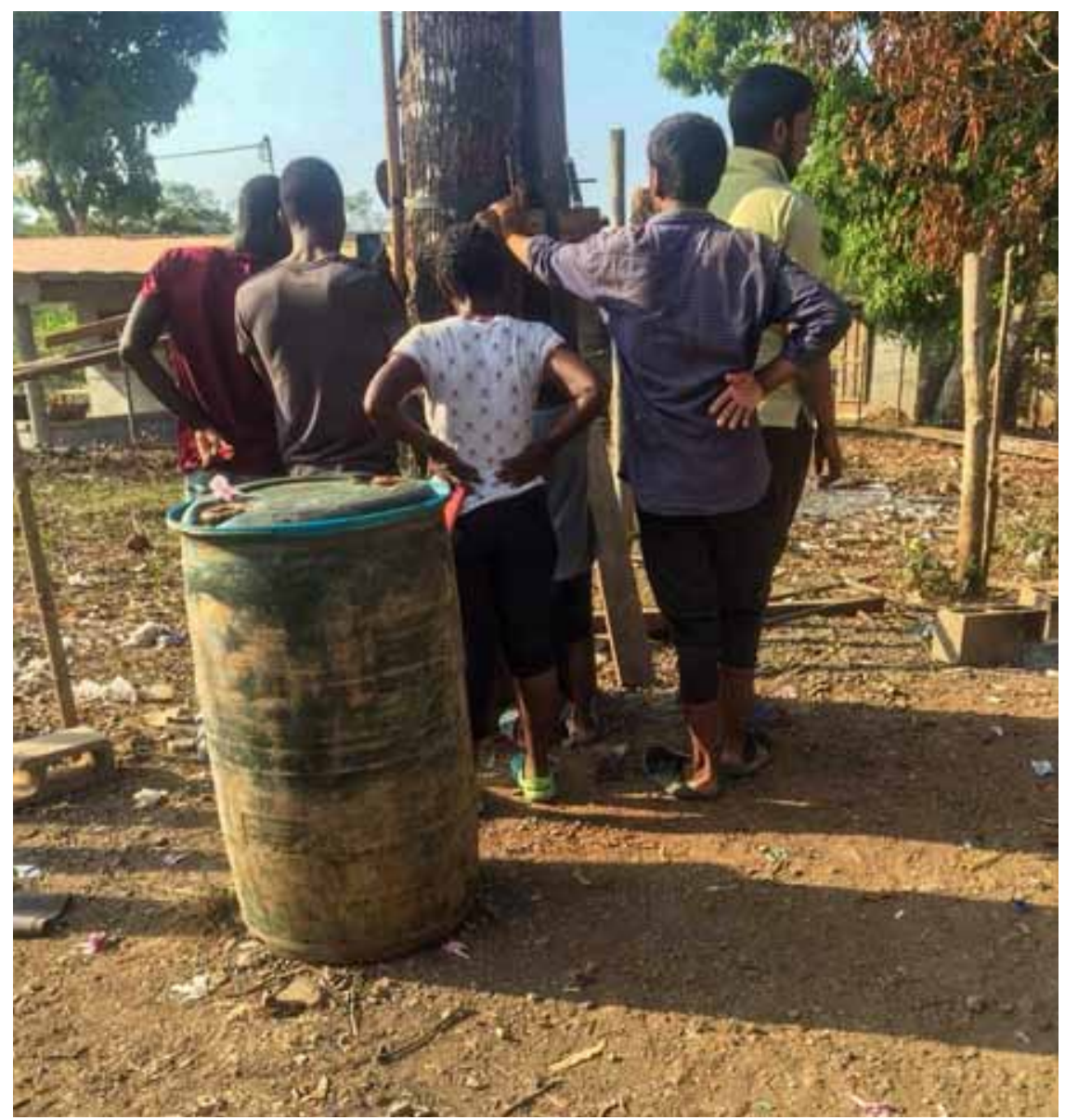

FIGURE 1: Using cell phones (put up against the tree) in La Peñita. Photograph taken and shared by Stella, March 2019. When I asked her permission to use her pictures, Stella agreed but added: "The pictures are bad because I didn't want [the police] to catch me taking them!”

asylum and repatriation options that I was looking into with a local humanitarian organization, but the next day I received a more confident voice message, in which Stella explained that when she had sent me the previous messages, she felt frustrated because she had not been able to talk to her family. She had also been under the wrong impression that she would have to stay in the shelter for two months. Stella felt better the following day, having "accepted the situation" even though the conditions were appalling. She sighed, "But I can't choose, can I? And I can't come a long way like this to just go back." Now she was learning the dynamics of the place, linking up with other migrants, 
strategizing ways to leave, and praying that the green river water-used for bathing-would not give her an infection again.

In other words, Stella was navigating this particular leg of her journey through volatile terrain. Henrik Vigh (2009: 420) reminds us that the term 'navigation' refers to sailing the sea, and thus to "the way we move in a moving environment." It "highlights people's efforts to gain an overview, envision possible trajectories and predict future configurations of their (social) environments; it accentuates the way people imagine the unfolding of their worlds as well as the way that these images of possible and probable futures affects their acts in the here and now" (ibid.: 428). In the context of Stella's journey, the 'moving environment' that requires navigation includes changing migration and integration policies, geopolitical interests, humanitarian interventions, border actors and economies, as well as the absence/presence of researchers (see Andersson 2014). Navigation also depends on the context-specific intersectional social positionings through which people hold differential power for navigating. This includes differentiated access to mobile communication technology and, when on the move, differentiated access to the increasingly diverse group of persons who become part of a journey.

As one of those persons, I grew increasingly worried for Stella's well-being, not only because of conditions in La Peñita, but also due to the upcoming challenges of the route I thought she would take next. I should have known by then that Stella was already many steps ahead of me, finding ways to keep herself and her baby safe and move north as soon as possible. Although I may have been instrumental in her initial navigation of this particular environment, I was now the one who had trouble keeping up with her. In fact, the way she navigated through her smartphone constantly surprised me. When she first texted me after meeting at the clinic, I was pleased, not expecting to hear from her given the dire circumstances. The profile picture of her WhatsApp account, showing a radiant, confident, and well-groomed young lady, caught me off guard, too. And then she continued to surprise me by sending detailed pictures, social commentaries, and travel updates. She used her smartphone to visibilize and share her indignation, allowing our relationship to move beyond the direness of our first encounter to a more mediated but at the same time more instructive exchange along the route of her journey. By initiating and sustaining contact, Stella substantially extended my field site to what had so far been off limits. Moreover, she extended my view of migrant agency and experience.

There are several things that I would have missed without the help of mobile communication technology-specifically, Stella's use of the technology to navigate a migration terrain that included me as a researcher. Without the calls and texts from Stella and her family, I would still have my first image of her stuck in my head, of how she had arrived at the hospital and was put in a wheelchair, tired, in ill health, and seemingly defeated. Although exhaustion and injury 
reflect important realities of this migrant journey, and although Stella may have needed to underline these realities in order to receive the care she needed, keeping in touch beyond our brief encounters at the hospital gradually transformed those initial impressions of the abject, suffering migrant. Stella's beauty, selfconfidence, and self-determination were now evident. Her intimate connections with others and elsewhere helped me to think of trajectories beyond migrants themselves. Crucially, Stella became a constant reminder of what Shahram Khosravi (2018: 294) calls migrants' "right to opacity," because she did not share all her travel details with me. Contradicting earlier statements or silencing new questions, she kept in touch on her own terms.

These reminders of migrants as full human beings and consequently their right to opacity are important, as researchers' quest to understand routes and strategies by following people on the move can inadvertently result in increased marginalization, criminalization, and deportation, compromising our ethical obligation not to endanger research participants. Referring to colonial practices aimed at "knowing" colonized subjects, Khosravi (2018: 294) writes about the dangers of revelatory trajectory research and argues that there is "palpable violence" implied in a researcher's demand for transparency. Moreover, portrayals of clandestine suffering are easily appropriated politically to incite fear and to dehumanize people on the move (Andersson 2014). Such othering mechanisms are of central concern in anthropology, and the social sciences more broadly, and require continuous reflection, not only on how we generate data and how much of it we reveal, but also on how we may enable our research participants to present themselves as multi-dimensional human beings. Radhika Gajjala (2002) suggests that acknowledging the active online participation and selfrepresentation of her research participants decreased some of the material and cultural distance that would otherwise have exacerbated their othering.

Similarly, a focus on research participants' use of smartphones for navigating their social environment can encourage non-violent portrayals that humanize people on the move and, by extension, others prone to dehumanizing generalizations. In taking over our conversation, Stella displayed her agency and redefined the empirical, ethical, and methodological research field. In empirical terms, she showed me how a combination of on-site and at-distance fieldwork may enable a better grasp of the shaping and navigating of migrant trajectories. At the same time, her mobile interventions-or reverse followingforced me to reconsider our communication in an ethical sense. Stella inspired me to reflect on possibilities for countering the risks of othering-through-following methodologically by enabling and being susceptive to the ways research participants themselves use ambiguous communication technology to take over the conversation. Acknowledging these redefinitions of the field may offer a useful starting point for critical explorations of online connectivity and disconnectivity in our research encounters. 


\section{Looking Back}

The last time I spoke with Stella over the phone, in February 2020, she was in a safe place. Her baby had been born right after arriving there, and the little girl was growing just fine. Telling me about her initial doubts as a first-time mom, Stella shares something that she knows I will appreciate and again emphasizes the aspects of her identity that take me beyond an ongoing concern with how she suffered while traveling. The suffering is still present, though: when she looks back on the journey, she gets goosebumps. Speaking of her reception in Panama, she says: "If other governments would know what they do, they would be in trouble. That's why they took me out of the [health clinic], they thought you were a journalist and they did not want me to speak to you." Looking back, she says you couldn't pay her to go through the journey again: "I was in so much danger." But then her voice becomes fierce: "I want the story to get out. People should know what is happening. I know we come into their country illegally, but no one walks from peace to peace. You take the road from trouble to peace, because your life is in danger, because you're not safe."

\section{Acknowledgments}

I would like to thank the organizers and participants of the "Staying Tuned" panel at the 16th EASA Biennial Conference in virtual Lisbon for their enriching insights, and the guest editors for their thorough review. Thanks to the research participants in Central America, the sisters of Centro Pastoral de las Hermanas Maryknoll in Santa Fe, and the teams of Servicio Jesuita para Migrantes Panamá (Panama City) and Defensoría del Pueblo (Oficina Regional Darién, Metetí) for their assistance. Thank you, Stella, for allowing me a glimpse of your journey.

Nanneke Winters is an Assistant Professor in Migration and Development at the International Institute of Social Studies (ISS), Erasmus University Rotterdam. Her research interests include im/mobility, migrant trajectories, and translocal livelihoods in Central America and beyond. Her research collaborations have been funded by the Research Foundation - Flanders (FWO) and the German Research Fund (DFG), and her work has been published in a variety of journals including International Migration Review and Geoforum. Before joining ISS, she held research positions in the Department of Anthropology and African Studies at the Johannes Gutenberg University Mainz and in the Department of Human Geography and Spatial Planning at Utrecht University. E-mail: winters@iss.nl 


\section{Notes}

1. A pseudonym in honor of her daughter.

2. This project was generously funded by the German Research Foundation (DFG), grant number: 406978565.

3. Some of this critique reflects earlier discussions of multi-sited ethnography (Falzon 2009), including issues of possible fragmentation, lack of depth, and arbitrary site selection.

\section{References}

Andersson, Ruben. 2014. Illegality, Inc.: Clandestine Migration and the Business of Bordering Europe. Oakland: University of California Press.

Benítez, José Luis. 2006. "Transnational Dimensions of the Digital Divide among Salvadoran Immigrants in the Washington DC Metropolitan Area." Global Networks 6 (2): 181-199.

De León, Jason. 2015. The Land of Open Graves: Living and Dying on the Migrant Trail. Oakland: University of California Press.

Drotbohm, Heike, and Nanneke Winters. 2021. "A Shifting yet Grounded Transnational Social Field: Interplays of Displacement and Emplacement in African Migrant Trajectories across Central America.” Population, Space and Place. https://doi.org/10.1002/psp.2421.

Elliot, Alice, Roger Norum, and Noel B. Salazar, eds. 2017. Methodologies of Mobility: Ethnography and Experiment. New York: Berghahn Books.

Falzon, Mark-Anthony. 2009. “Introduction.” In Multi-Sited Ethnography: Theory, Praxis and Locality in Contemporary Research, ed. Mark-Anthony Falzon, 1-23. Farnham: Ashgate.

Gajjala, Radhika. 2002. “An Interrupted Postcolonial/Feminist Cyberethnography: Complicity and Resistance in the 'Cyberfield.'” Feminist Media Studies 2 (2): 177-193.

Girot, Pascal O. 2002. "The Darien Region between Colombia and Panama: Gap or Seal?” In Human Rights and the Environment: Conflicts and Norms in a Globalizing World, ed. Lyuba Zarsky, 172-197. London: Earthscan Publications.

Khosravi, Shahram. 2018. "Afterword: Experiences and Stories Along the Way." Geoforum 116: 292-295.

Mahler, Sarah J. 2001. "Transnational Relationships: The Struggle to Communicate Across Borders." Identities: Global Studies in Culture and Power 7 (4): 583-619.

Merriman, Peter. 2014. "Rethinking Mobile Methods.” Mobilities 9 (2): 167-187.

Salazar, Noel B., Alice Elliot, and Roger Norum. 2017. "Introduction: Studying Mobilities. Theoretical Notes and Methodological Queries.” In Elliot et al. 2017, $1-24$.

Schapendonk, Joris, and Griet Steel. 2014. "Following Migrant Trajectories: The Im/mobility of Sub-Saharan Africans en Route to the European Union." Annals of the Association of American Geographers 104 (2): 262-270. 
Vigh, Henrik. 2009. "Motion Squared: A Second Look at the Concept of Social Navigation.” Anthropological Theory 9 (4): 419-438.

Walton, Shireen. 2017. “'Being There Where?’ Designing Digital-Visual Methods for Moving With/In Iran.” In Elliot et al. 2017, 148-171.

Winters, Nanneke. 2019. “Haciendo-lugar en tránsito: Reflexión sobre la migración africana y trabajo de campo en Darién, Panamá” [Place-making in transit: Reflections on African migration and fieldwork in Darién, Panama]. REMHU: Revista Interdisciplinar da Mobilidade Humana 27 (56). https://doi. org/10.1590/1980-85852503880005613.

Yates, Caitlyn. 2019. “As More Migrants from Africa and Asia Arrive in Latin America, Governments Seek Orderly and Controlled Pathways.” Migration Information Source, 22 October. https://www.migrationpolicy.org/article/ extracontinental-migrants-latin-america.

Zijlstra, Judith, and Ilse van Liempt. 2017. "Smart(phone) Travelling: Understanding the Use and Impact of Mobile Technology on Irregular Migration Journeys.” International Journal of Migration and Border Studies 3 (2-3): 174-191. 